\title{
IMBANGAN PROTEIN DAN ENERGI BERBEDA DALAM RANSUM PUYUH FASE GROWER TERHADAP KONSUMSI PAKAN, PERTAMBAHAN BOBOT BADAN, DAN KONVERSI RANSUM
}

\author{
Astriana Napirah, Hamdan Has, La Ode Nafiu, Ali Bain, Takdir Saili \\ Fakultas Peternakan, Universitas Halu Oleo \\ Email: has.hamdan@yahoo.co.id
}

\begin{abstract}
ABSTRAK
Kandungan energi dan protein pakan merupakan faktor yang mempengaruhi kualitas pakan dan performans produksi ternak. Penelitian ini bertujuan untuk mempelajari pengaruh imbangan energi dan protein berbeda dalam ransum puyuh fase grower terhadap konsumsi pakan, perrtambahan bobot badan, dan konversi pakan. Seratus dua puluh DOQ disebar secara acak pada 24 unit kandang percobaan. Perlakuan yang dicobakan terdiri atas 2 level energi pakan (2700 dan $2900 \mathrm{kkal} / \mathrm{kg})$ dan 3 level protein pakan $(18,20$, dan 22\%), sehingga terdapat 6 kombinasi perlakuan, yaitu R1 (2700 EM - 18\% PK), R2 (2700 EM - 20\% PK), R3 (2700 EM - 22\% PK), R4 (2900 EM - 18\% PK), R5 (2900 EM - 20\% PK), dan R6 (2900 EM $-22 \%$ PK). Pakan yang dicobakan merupakan pakan self mixing. Parameter yang diamati adalah konsumi pakan, pertambahan bobot badan, dan konversi pakan puyuh umur 2 hingga 6 minggu. Data yang diperoleh dianalisis menggunakan analisis ragam dan dilanjutkan dengan uji wilayah berganda duncan. Hasil penelitian menunjukkan bahwa imbangan energi-protein pakan berbeda tidak memberikan pengaruh $(\mathrm{P}>0,05)$ pada konsumsi pakan, pertambahan bobot badan, dan konversi pakan. Kombinasi energi metabolisme $2700 \mathrm{kkal} / \mathrm{kg}$ dan 18\% protein sudah dapat memenuhi kebutuhan nutrisi puyuh periode grower.
\end{abstract}

Kata Kunci: protein, energi, puyuh, grower

\begin{abstract}
Energy and protein that contained in poultry feed is a factor that affect the feed quality and poultry production performance. This research aimed to study the effect of different energy and protein balance in quail feed on feed consumption, weight gain, and feed conversion ratio. One hundred and twenty day old quails were divided into 24 units enclosure research. The trial feed was consist of 2 levels of energy feed $(2700$ and $2900 \mathrm{kcal} / \mathrm{kg})$ and 3 levels of crude protein $(18,20$, and $22 \% \mathrm{CP})$, so that there were 6 combinations of treatments, i.e. R1 (2700 ME - 18\% CP), R2 (2700 ME - 20\% CP), R3 (2700 ME - 22\% CP), R4 (2900 ME - 18\% CP), R5 (2900 ME - 20\% CP), R6 (2900 ME - 22\% CP). The used feed was a self mixing feed. The observed parameters were feed consumption, body weight gain, and feed conversion ratio of quail at 2-6 weeks of age. The data obtained were analyzed using variance analysis and continued using Duncan's multiple range test. The result showed that the balance of energy-protein in quail feed did not affect $(\mathrm{P}>0,05)$ feed consumption, body weight gain, and feed conversion ratio. The combination of $2700 \mathrm{kcal} / \mathrm{kg}$ metabolizable energy and $18 \%$ cruse protein could already maintain the needs of the grower period of quail nutrients.
\end{abstract}

Keywords: protein, energy, quail, grower 


\section{PENDAHULUAN}

Puyuh merupakan ternak unggas yang memiliki potensi pengembangan baik sebagai unggas pedaging maupun penghasil telur. Ternak puyuh digemari masyarakat karena memiliki beberapa kelebihan seperti mencapai dewasa kelamin pada umur relatif muda (Gheisari et al., 2011), memiliki produksi telur yang cukup tinggi (Mosaad dan Iben, 2009), daging dan telur puyuh memiliki nilai nutrisi tinggi (Genchev et al., 2008; Genchev, 2012), dan pemeliharaannya tidak memerlukan lahan yang luas. Namun demikian, salah satu permasalahan yang dialami peternak puyuh adalah terbatasnya ketersediaan pakan komersil bagi ternak puyuh di pasaran. Selain itu, standar kebutuhan nutrisi puyuh juga masih cukup beragam. Hal ini menyebabkan peternak mengalami kesulitan dalam menyediakan pakan berkualitas yang dapat memenuhi kebutuhan nutrisi ternak puyuh yang dipelihara. Mengatasi masalah ini, maka perlu dilakukan penentuan standar kebutuhan nutrisi puyuh, terutama imbangan energi-protein pakan. Imbangan energi-protein merupakan salah satu aspek yang mempengaruhi kualitas pakan dan menentukan produktivitas puyuh. Kandungan energi pakan dapat mempengaruhi produktivitas ternak (Kaur et al., 2008). Kandungan energi pakan harus diimbangi dengan kandungan protein pakan yang cukup. Kandungan protein pakan yang rendah dapat menurunkan pertambahan bobot badan (Kamran et al., 2008), sedangkan kandungan protein pakan yang tinggi dapat meningkatkan pertambahan bobot badan puyuh (Gheisari et al., 2011). Berdasarkan hal tersebut, maka dirasa perlu dilakukan penelitian untuk mencari imbangan energi-protein pakan puyuh yang tepat bagi puyuh periode grower, sehingga dapat menunjang performans ternak yang optimal.

\section{MATERI DAN METODE}

Penelitian ini menggunakan 120 ekor DOQ puyuh yang tidak dibedakan jenis kelaminnya (mixed sex) dan dibagi pada 24 unit kandang percobaan. Setiap unit kandang puyuh berukuran $30 \times 30$ x 40 $\mathrm{cm}$. Pakan yang digunakan adalah pakan self-mixing, dengan susunan komposisi pakan ditampilkan pada Tabel 1. Perlakuan yang dicobakan terdiri atas 2 level kandungan energi pakan (2700 dan 2900 $\mathrm{kkal} / \mathrm{kg}$ ) dan 3 level kandungan protein pakan (18, 20, dan 22\%). Kombinasi perlakuan yang dicobakan adalah sebagai berikut:
$\mathrm{R} 1$ = Energi metabolisme $2700 \mathrm{kkal} / \mathrm{kg}$, protein kasar $18 \%$
$\mathrm{R} 2$ = Energi metabolisme $2700 \mathrm{kkal} / \mathrm{kg}$, protein kasar 20\%
$\mathrm{R} 3$ = Energi metabolisme $2700 \mathrm{kkal} / \mathrm{kg}$, protein kasar $22 \%$
$\mathrm{R} 4=$ Energi metabolisme $2900 \mathrm{kkal} / \mathrm{kg}$, protein kasar $18 \%$
$\mathrm{R} 5$ = Energi metabolisme $2900 \mathrm{kkal} / \mathrm{kg}$, protein kasar 20\%
R6 = Energi metabolisme $2900 \mathrm{kkal} / \mathrm{kg}$, protein kasar $22 \%$

Parameter yang diamati adalah konsumsi pakan, pertambahan bobot badan, dan konversi pakan. Pengamatan dilakukan selama 5 minggu, sejak puyuh berumur 2 minggu dan berakhir saat puyuh berumur 6 minggu. Data yang diperoleh dianalisis menggunakan analisis ragam dan jika terdapat pengaruh nyata, analisis dilanjutkan dengan uji wilayah berganda Duncan (Duncan's multiple range test). 
Tabel 1. Komposisi pakan perlakuan

\begin{tabular}{|c|c|c|c|c|}
\hline Perlakuan & Bahan Penyusun & Komposisi (\%) & $\begin{array}{l}\text { Kandungan Energi } \\
\text { Total }(\mathrm{kkal} / \mathrm{kg})\end{array}$ & $\begin{array}{c}\text { Kandungan Protein } \\
\text { Total }(\%)\end{array}$ \\
\hline \multirow{3}{*}{$\mathrm{R} 1$} & Dedak padi & 29 & & \\
\hline & Jagung & 42 & 2700 & 18 \\
\hline & Konsentrat $\mathrm{CAB}$ & 29 & & \\
\hline \multirow{3}{*}{$\mathrm{R} 2$} & Dedak padi & 29 & & \\
\hline & Jagung & 35 & 2700 & 20 \\
\hline & Konsentrat $\mathrm{CAB}$ & 36 & & \\
\hline \multirow{3}{*}{ R3 } & Dedak padi & 25 & & \\
\hline & Jagung & 33 & 2700 & 22 \\
\hline & Konsentrat CAB & 42 & & \\
\hline \multirow{3}{*}{ R4 } & Dedak padi & 17 & & \\
\hline & Jagung & 53 & 2900 & 18 \\
\hline & Konsentrat CAB & 30 & & \\
\hline \multirow{3}{*}{ R5 } & Dedak padi & 16 & & \\
\hline & Jagung & 47 & 2900 & 20 \\
\hline & Konsentrat CAB & 37 & & \\
\hline \multirow{3}{*}{ R6 } & Dedak padi & 11 & & \\
\hline & Jagung & 45 & 2900 & 22 \\
\hline & Konsentrat $\mathrm{CAB}$ & 44 & & \\
\hline
\end{tabular}

Parameter yang diamati adalah konsumsi pakan, pertambahan bobot badan, dan konversi pakan. Pengamatan dilakukan selama 5 minggu, sejak puyuh berumur 2 minggu dan berakhir saat puyuh berumur 6 minggu. Data yang diperoleh dianalisis menggunakan analisis ragam dan jika terdapat pengaruh nyata, analisis dilanjutkan dengan uji wilayah berganda Duncan (Duncan's multiple range test).

\section{HASIL DAN PEMBAHASAN}

Performa produksi puyuh fase grower pada imbangan energi-protein pakan berbeda ditampilkan pada Tabel 2 . Hasil penelitian menunjukkan bahwa imbangan energi-protein pakan berbeda tidak memberikan pengaruh pada konsumsi pakan, pertambahan bobot badan, dan konversi pakan puyuh grower (umur 2-6 minggu).

Hasil penelitian menunjukkan bahwa pada setiap tingkatan umur, imbangan energi-protein pakan yang berbeda tidak mempengaruhi $(\mathrm{P}>0,05)$ konsumsi pakan puyuh. Terdapat kecenderungan bahwa nilai konsumsi pakan mengalami peningkatan sampai puyuh berumur 5 minggu. Setelah itu, konsumsi pakan puyuh cenderung mengalami penurunan. Hasil penelitian ini sejalan dengan hasil penelitian Gheisari et al. (2011) yang melaporkan bahwa level energi pakan yang berbeda tidak memberikan pengaruh terhadap konsumsi pakan puyuh umur 1 - 49 hari. Gaol et al. (2015) juga melaporkan hal serupa bahwa kandungan energi pakan berbeda akibat penggunaan roti afkir sebagai pakan puyuh tidak memberikan pengaruh signifikan pada konsumsi pakan.

Perubahan bobot badan merupakan hal paling penting baik dalam aspek breeding maupun manajemen pemeliharaan ternak (Narinc et al., 2010). Hasil penelitian menunjukkan bahwa imbangan energiprotein pakan berbeda tidak memberikan pengaruh $(\mathrm{P}>0,05)$ pada pertambahan bobot 
badan puyuh di setiap tingkatan umur. Terdapat kecenderungan bahwa pertambahan bobot badan rata-rata mengalami peningkatan sampai puyuh berumur 4 minggu. Setelah melewati umur tersebut, pertambahan bobot badan yang terjadi relatif lebih kecil, bahkan menurun. Gheisari et al. (2011) melaporkan hal serupa bahwa level energi pakan berbeda tidak mempengaruhi pertambahan bobot badan puyuh umur 1-49 hari. Selanjutnya Gaol et al. (2015) memaparkan bahwa kandungan energi pakan berbeda (2800, 2935, $3070 \mathrm{kkal} / \mathrm{kg}$ ) tidak memberikan pengaruh signifikan pada pertambahan bobot badan puyuh. Hal serupa juga dilaporkan oleh Mosaad dan Iben (2009) bahwa level energi pakan tidak memberikan pengaruh pada pertambahan bobot badan puyuh, tetapi level protein pakan secara nyata mempengaruhi pertambahan bobot badan puyuh.

Tabel 2. Konsumsi pakan, pertambahan bobot badan, dan konversi pakan puyuh grower pada imbangan energiprotein pakan berbeda

\begin{tabular}{|c|c|c|c|c|c|}
\hline \multirow{2}{*}{ Parameter/ Perlakuan } & \multicolumn{5}{|c|}{ PENGAMATAN MINGGU KE- } \\
\hline & 1 & 2 & 3 & 4 & 5 \\
\hline Konsumsi Pakan & \multicolumn{5}{|c|}{ g/ekor/minggu } \\
\hline $\mathrm{R} 1$ & $134,50 \pm 24,5$ & $138,50 \pm 18,44$ & $160,75 \pm 18,83$ & $177,25 \pm 24,70$ & $118,25 \pm 15,71$ \\
\hline $\mathrm{R} 2$ & $131,00 \pm 20$ & $150,50 \pm 19,01$ & $162,75 \pm 14,54$ & $156,75 \pm 28,37$ & $93,5 \pm 14,38$ \\
\hline $\mathrm{R} 3$ & $121,75 \pm 8,38$ & $141,00 \pm 19,14$ & $149,25 \pm 15,77$ & $157,00 \pm 15,34$ & $104,58 \pm 13$ \\
\hline R4 & $128,50 \pm 12,06$ & $134,50 \pm 21,04$ & $144,00 \pm 18,16$ & $188,73 \pm 17,53$ & $77,84 \pm 13,00$ \\
\hline R5 & $128,50 \pm 12,06$ & $134,50 \pm 21,04$ & $144,00 \pm 18,16$ & $164,58 \pm 17,53$ & $87,265 \pm 13,00$ \\
\hline R6 & $118,25 \pm 11,05$ & $138,16 \pm 21,96$ & $146,75 \pm 5,12$ & $185,33 \pm 29,36$ & $124,99 \pm 24,98$ \\
\hline Pertambahan Bobot Badan & \multicolumn{5}{|c|}{ g/ekor/minggu } \\
\hline $\mathrm{R} 1$ & $33,25 \pm 4,11$ & $31,00 \pm 9,90$ & $27,00 \pm 4,49$ & $18,00 \pm 11,16$ & $10,75 \pm 3,08$ \\
\hline $\mathrm{R} 2$ & $40,25 \pm 5,12$ & $32,00 \pm 5,54$ & $22,50 \pm 3,91$ & $17,75 \pm 7,27$ & $8,50 \pm 7,41$ \\
\hline R3 & $30,25 \pm 4,94$ & $30,25 \pm 3,91$ & $21,50 \pm 3,83$ & $12,25 \pm 4,11$ & $9,00 \pm 2,94$ \\
\hline R4 & $34,50 \pm 3,80$ & $26,05 \pm 2,19$ & $23,45 \pm 1,64$ & $21,75 \pm 9,74$ & $7,00 \pm 2,44$ \\
\hline R5 & $36,75 \pm 7,18$ & $26,00 \pm 2,19$ & $19,50 \pm 2,19$ & $22,75 \pm 2,19$ & $7,75 \pm 4,42$ \\
\hline R6 & $31,00 \pm 6,68$ & $32,75 \pm 2,19$ & $20,25 \pm 2,19$ & $21,50 \pm 8,99$ & $11,25 \pm 8,9$ \\
\hline \multicolumn{6}{|l|}{ Konversi Pakan } \\
\hline $\mathrm{R} 1$ & $4,02 \pm 0,68$ & $4,55 \pm 1,41$ & $5,95 \pm 1,89$ & $9,84 \pm 1,17$ & $11,00 \pm 0,81$ \\
\hline $\mathrm{R} 2$ & $3,27 \pm 0,40$ & $4,77 \pm 1,29$ & $7,23 \pm 0,74$ & $8,83 \pm 0,77$ & $11,00 \pm 0,81$ \\
\hline R3 & $4,02 \pm 0,38$ & $4,62 \pm 0,81$ & $6,94 \pm 1,07$ & $8,55 \pm 0,63$ & $11,62 \pm 0,74$ \\
\hline R4 & $3,75 \pm 0,68$ & $5,55 \pm 0,64$ & $6,14 \pm 0,78$ & $8,65 \pm 1,55$ & $11,12 \pm 0,85$ \\
\hline R5 & $3,57 \pm 0,51$ & $5,35 \pm 1,81$ & $7,38 \pm 1,99$ & $8,30 \pm 0,60$ & $11,26 \pm 0,81$ \\
\hline R6 & $3,87 \pm 0,57$ & $4,10 \pm 1,37$ & $7,24 \pm 0,61$ & $8,62 \pm 0,75$ & $11,11 \pm 0,76$ \\
\hline
\end{tabular}

Hasil penelitian menunjukkan bahwa konversi pakan puyuh tidak dipengaruhi $(\mathrm{P}>0,05)$ oleh imbangan energi-protein pakan yang berbeda. Terdapat kecenderungan bahwa semakin tua umur puyuh, nilai konversi pakan semakin besar. Hal serupa juga dijelaskan oleh Gheisari et al. (2011) dan Gaol et al. (2015), bahwa kandungan energi pakan berbeda tidak memberikan pengaruh pada nilai konversi pakan puyuh.

Hasil yang diperoleh pada penelitian ini menunjukkan bahwa bagi puyuh umur $2-6$ minggu, imbangan energi-protein pakan yang berbeda tidak memberikan pengaruh pada konsumsi pakan, pertambahan bobot badan, dan konversi pakan. Tidak terdapat interaksi 
yang signifikan antara level energi dan protein pakan dalam mempengaruhi nilai konsumsi pakan, pertambahan bobot badan, dan konversi pakan. Performans produksi puyuh umur $2-6$ minggu secara statistik sama pada semua level imbangan energiprotein pakan. Terdapat kecenderungan bahwa semakin tua umur puyuh, efisiensi pakan dan kecepatan pertumbuhannya semakin rendah.

\section{PENUTUP}

Dapat disimpulkan bahwa imbangan energi-protein pakan berbeda tidak mempengaruhi konsumsi pakan, pertambahan bobot badan, dan nilai konversi pakan puyuh. Kombinasi energi pakan $2700 \mathrm{kkal} / \mathrm{kg}$ dengan kandungan protein $18 \%$ sudah dapat memenuhi kebutuhan nutrisi puyuh pada periode grower.

\section{DAFTAR PUSTAKA}

Gaol, S. E. L., L. Silitonga, I. Yuanita. 2015. Substitusi Ransum Jadi dengan Roti Afkir Terhadap Performa Burung Puyuh (Coturnix-coturnix japonica) Umur Starter Sampai Awal Bertelur. Jurnal Ilmu Hewani Tropika. 4(2):61-65.

Genchev, A., G. Mihaylova, S. Ribarski, A. Pavlov, and M. Kabakchiev. 2008. Meat quality and composition in japanese quails. Trakia Journal of Science. 6(4):72-82.

Genchev, A. Quality and composition of japanese quail eggs (Coturnix japonica). Trakia Journal of Science. 10(2):91-101.

Gheisari, A., H. A. Halaji, G. Maghsoudinegad, M. Toghyani, A. Alibemani, and S. E. Saeid. 2011. Effect of Different Dietary Levels of energy and Protein on Performance of Japanese Quails (Coturnix-coturnix japonica). Proceeding of 2nd
International Conference on Agricultural And Animal Science. Maldives, 25-27 November 2011. Page. 156-159.

Kamran, Z., M. Sarwar, M. Nisa, M. A. Nadeem, S. Mahmood, M. E. Babar, and S. Ahmed. 2008. Effect of LowProtein Diets Having Constant Energy-to-Protein Ratio on Performance and Carcass Characteristics of Broiler Chckens from One to Thirty-Five Days of Age. Poultry Science 87(3):468-474.

Kaur, S., A. B. Mandal, K. B. Singh, M. M. Kadam. 2008. Response of Japanese Quails (heavy body weight) to Dietary energy Levels and Graded Essential Amino Acids Levels on Growth Performance and ImmunoCompetence. Livestock Science 117: 255-262.

Mosaad, G. M. M. and C. Iben. 2009. Effect of Dietary Energy and Protein Levels on Growth Performance, Carcass Yield and Some Blood Constituents of Japanese Quails (Coturnix-coturnix japonica). Die Bodenkultur 60(4):39-46.

Narinc, D., E. Karaman, M. Z. Firat, and T. Aksoy. 2010. Comparison of Nonlinear Growth Models to Describe the Growth in Japanese Quail. Journal of Animal and Veterinary Advances. 9(14):1961-1966. 